Technical Note

\title{
A METHODOLOGY TO SELECT A GROUP OF SPECIES AMONG 131 TROPICAL (COLOMBIAN) SPECIES FOR BOWED TIMBER APPLICATIONS
}

\author{
Natalia Caicedo-Llano ${ }^{1}$
}

In memoriam of Dr. Manfred SCHWANNINGER

\begin{abstract}
We present a methodology of selecting wood species for architectural purposes, especially when a curved shape is required. First, a mechanical criterion is associated with a morphology, more specifically a characteristic value of stress-strain relation is associated with the attitude of wood for bowing. Second, a filtering is done using data of wood in the green state and in the dry state, and then the wood selection is refined by using relevant criteria related to environment and economic considerations. The following four species are the result of the selection: Sande or Guaimaro (Brosimum utile), Ceiba (Ceiba pentandra), Tamarindo (Dialum guianense), and Roble flor morado (Tabebuia rosea). Information given in the literature is complemented with results of bending experiments when information is lacking. The result emphasizes that tropical species are fitter than temperate species for bowed wood applications.
\end{abstract}

Keywords: Tropical wood, colombian species, bowing timber, Brosimum utile, Ceiba pentandra, Dialum guianense, Tabebuia rosea.

\section{INTRODUCTION}

The research is motivated from a structural point of view by the fact that a timber element with the same section can support more load when working as an arch than as a straight beam. Thus, a curved construction system is more efficient in terms of volume of material per applied load. Nevertheless, the use of arches rises by economic and environmental considerations as: cambered beams are often made in glulam. Hence the interest we attach to the possibility of building arched structures by bowing green timbers in the required shape instead of technologies requiring more transformation (e.g. drying, laminating, gluing).

Most species can be bent in the green state soon after falling, reducing the time and the cost of drying, and thus making the constructive system better from an environmental and economic point of view.

According to reference (U.D.F.J.C. 2010), in Colombia, there are 4681 botanical species with more than one thousand that can be considered as wood. For the purpose of the research we create a database with information from different references (A.I.S. 2010, Gerard 2008, Hernández-Córdoba 2006, J.U.N.A.C. 1984, Lastra-Rivera 1987, Lopez et al. 2010, Nieto et al. 1998, Nieto 2004, Obregón-Sánchez 2005, Proexport 1980, Proexport 2009, Rojas-Gutiérrez 2008, Escobar and Rodriguez 1993, Salazar 2010, UDFJC 2010, Sautu et al. 2006, Triana-Gómez et al. 2008, Vázquez et al. 1999, Vásquez-Correa and Ramírez-Arango 2005) regarding 200 species and mechanical information regarding 131 species. 
A similar methodology to select a group of species is proposed by (Teranishi et al. 2008) but in this case the evaluation of quality indexes of bending performance and hardness for hardwoods is done only through impact tests done on site. This methodology can be more precise but it requires a lot of resources. The fact that there are similar methods to give an answer to the same question shows that there is a need on this subject in developing countries.

The aim of this paper is to develop a methodology of selecting wood species to be used as bowed construction timber. It is important to highlight the difference between to bend and to bow. Bending refers to the deflection taken by a beam when loaded, usually considered as a small and reversible effect which does not alter the nominal geometry of the structure. Bowing, more specifically, is the effect of bending into the shape of a bow by curving it, and can be used to generate the nominal geometry of a structure.

\section{MATERIALS AND METHODS}

First, a selection of species more suitable for bowing is done using a database created for the purpose of this paper allowing the comparison of species according to some criteria which will be presented in section materials and methods for the selection of species. This database is first made starting from the literature, and then upgraded with information obtained from experiments which will be presented in the same section. Verification tests are necessary because values in the literature are often not consistent with each other.

\section{Materials and methods for the selection of species}

We developed a database of Colombian wood species taken as starting point a database created by the research laboratory "Madera y Guadua" of the "Universidad Nacional de Colombia". Modifications made to this database are: the addition of categories (origin and conservation of species, geographic location), the addition of subcategories in existent categories (age of maturity, yield, annual increment), the introduction of classifications to handle some qualitative information, and the indication of the bibliographic reference per data.

In Figure 1 an example is shown of an index card of one species from a total of 131 species. Information is compiled from the following references: (Escobar and Rodriguez 1993) corresponding to code B-37, (J.U.N.A.C. 1984) corresponding to code B-44, (Lastra-Rivera 1987) corresponding to code B-53, (Vásquez-Correa and Ramírez-Arango 2005) corresponding to code B-55, (Nieto et al. 1998) corresponding to code B-68, (Vázquez et al. 1999) corresponding to code B-76, (Lopez et al. 2010) corresponding to code D-02 (A.I.S. 2010) corresponding to code S-07, and (Salazar 2010) corresponding to code U-03A. Notice that this example is in English but the database is in Spanish. 
Colombian wood species

\begin{tabular}{|c|c|c|c|c|c|c|c|}
\hline \multicolumn{8}{|c|}{ Characteristics of the tree } \\
\hline & & & \multirow[t]{2}{*}{$\begin{array}{l}\text { Code of } \\
\text { the } \\
\text { reference }\end{array}$} & & & & $\begin{array}{l}\text { Code of } \\
\text { the } \\
\text { reference }\end{array}$ \\
\hline Code of the species & \multicolumn{2}{|l|}{25} & & \multirow{2}{*}{ Common names in english } & \multicolumn{2}{|l|}{ Alder } & D-02 \\
\hline Common name & \multicolumn{2}{|l|}{ Roble flor morado } & B-37 & & & \\
\hline Scientific name & \multicolumn{2}{|l|}{ Tabebuia rosea } & B-37 & Common names in french & \multicolumn{2}{|l|}{ Roble blanc, Amapa } & D-02 \\
\hline Scientist & \multicolumn{2}{|l|}{ Bertol } & & & & B-37 \\
\hline Synonymous of the & \multirow{2}{*}{\multicolumn{2}{|c|}{ Tabebuia pentaphylla (L.) Hemsl. }} & B-37 & Maximal height $(\mathrm{m})$ & \multicolumn{2}{|l|}{$\begin{array}{l}\text { Bignoniaceae } \\
25\end{array}$} & B-37 \\
\hline \multirow{5}{*}{ Other common names } & \multirow{5}{*}{\multicolumn{2}{|c|}{$\begin{array}{l}\text { Roble, Flormorado, Ocobo, } \\
\text { Otovo, Apamate, Chicalá, } \\
\text { Guayacán, Guayacán rosado, } \\
\text { Ocobo rosado, Palo colorado, } \\
\text { Polvillo, Roble de rio, Roble de } \\
\text { sabanaRoble morado, Roble } \\
\text { sabanero }\end{array}$}} & \multirow{5}{*}{ D-02 } & Diameter $(\mathrm{m})$ & \multicolumn{2}{|c|}{1} & B-76 \\
\hline & & & & Shape of trunk & \multicolumn{2}{|l|}{ Irregular and short } & B-37 \\
\hline & & & & Age of maturity (years) & & & \\
\hline & & & & Yield (m3/ha/year) & \multirow{2}{*}{\multicolumn{2}{|c|}{20}} & B-68 \\
\hline & & & & Annual increment $(\mathrm{cm})$ & & & \\
\hline \multicolumn{8}{|c|}{ Characteristics of the wood species } \\
\hline & & & $\begin{array}{l}\text { Code of } \\
\text { the } \\
\text { reference }\end{array}$ & & & & $\begin{array}{l}\text { Code of } \\
\text { the } \\
\text { reference }\end{array}$ \\
\hline Sapwood & \multicolumn{2}{|l|}{ Yellow } & B-37 & Qualitative capacity to dry & \multicolumn{2}{|l|}{ 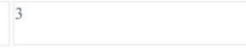 } & B-44 \\
\hline Heartwood & \multicolumn{2}{|c|}{$\begin{array}{l}\text { Hard to identify because it } \\
\text { gradually turns into brown }\end{array}$} & B-37 & $\begin{array}{l}\text { artificially } \\
\text { Preservation }\end{array}$ & \multirow{2}{*}{\multicolumn{2}{|c|}{$\begin{array}{l}\text { Easy to immunize with liquid } \\
\text { preservatives }\end{array}$}} & B-37 \\
\hline Texture & Varies from curved to it & nterlaced & B-37 & & & & \\
\hline & & & & Qualitative natural durability & $\begin{array}{l}\text { High natural durability to } \\
\text { putrefaction unless white }\end{array}$ & & B-37 \\
\hline $\begin{array}{l}\text { Qualitative capacity to } \\
\text { dry naturally }\end{array}$ & $\begin{array}{l}\text { Quite easy to dry natur: } \\
\text { needs time }\end{array}$ & ally but & B-37 & Quantitative natural durability & 4 & & B-37 \\
\hline $\begin{array}{l}\text { Quantitative capacity to } \\
\text { dry naturally }\end{array}$ & 3 & & B-37 & Qualitative natural durability & & & \\
\hline $\begin{array}{l}\text { Qualitative capacity } \\
\text { not to deform during }\end{array}$ & $\begin{array}{l}\text { Timber slightly wrappe } \\
\text { few cracks }\end{array}$ & $d$ and with & B-37 & Quantitative natural & & & \\
\hline Quantitative capacity & 3 & & B-37 & durability & & & \\
\hline $\begin{array}{l}\text { not to deform during } \\
\text { drying }\end{array}$ & & & & Impregnability & & & B-37 \\
\hline $\begin{array}{l}\text { Quantitative capacity } \\
\text { to dry naturally }\end{array}$ & 2 & & B-44 & Workability & Easy to work with & & B-37 \\
\hline Origin of species : & and for species for & conservat & ation & & & & \\
\hline & & & $\begin{array}{l}\text { Code of } \\
\text { the } \\
\text { reference }\end{array}$ & & & & $\begin{array}{l}\text { Code of } \\
\text { the } \\
\text { reference }\end{array}$ \\
\hline Species the IUCN list & & & & Origin of species & & & \\
\hline in Colombia & & & & Reforested species & Yes & & B-68 \\
\hline $\begin{array}{l}\text { Species the IUCN list } \\
\text { internationally }\end{array}$ & & & & & & & \\
\hline Geographic locati & & & & & & & \\
\hline & & & $\begin{array}{l}\text { Code of } \\
\text { the } \\
\text { reference }\end{array}$ & & & & $\begin{array}{l}\text { Code of } \\
\text { the } \\
\text { reference }\end{array}$ \\
\hline Location per region & $\begin{array}{l}\text { Canyon of Cauca's river } \\
\text { region of Magdalena, } \\
\text { Huila, Sarare (Arauca), } \\
\text { Cundinamarca, region }\end{array}$ & $\begin{array}{l}\text { central } \\
\text { olima, } \\
\text { f Urabá }\end{array}$ & B-37 & Location per region D-02 & $\begin{array}{l}\text { Cundinamarca, region } \\
\text { Urabá,Sierra Nevada do } \\
\text { Marta and the Amazoni }\end{array}$ & $\begin{array}{l}\text { of } \\
\text { e Santa } \\
\text { ian region }\end{array}$ & D-02 \\
\hline & $\begin{array}{l}\text { Cundinamarca, region o } \\
\text { and Córdoba. }\end{array}$ & & & Minimal location in altitude $(\mathrm{m})$ & 1) 0 & & D-02 \\
\hline & & & & Maximal location in altitude ( $\mathrm{m}$ & n) 2000 & & D-02 \\
\hline Mechanical prope & rties & & & & & & \\
\hline & & & $\begin{array}{l}\text { Code of } \\
\text { the } \\
\text { reference }\end{array}$ & & & & $\begin{array}{l}\text { Code of } \\
\text { the } \\
\text { reference }\end{array}$ \\
\hline Density $(\mathrm{g} / \mathrm{cm} 3)$ & & 0,54 & S-07 & Tension stress in the dry state (N & Mpa) & 110,04 & S-07 \\
\hline MOE in the dry state (N & $\mathrm{MPa})$ & 12400 & B-37 & Compression stress perp to grain & in in the dry state (MPa) & 6,53 & S-07 \\
\hline MOE in the green state & (MPa) & 12500 & B-37 & Shear stress in the dry state $\left(M_{p}\right.$ & & 13,13 & S-07 \\
\hline Bending stress in the dry & y state (Mpa) & 110,24 & S-07 & Bending stress in the green state & (MPa) & 82,03 & B-37 \\
\hline $\begin{array}{l}\text { Compression stress par t } \\
\text { (Mpa) }\end{array}$ & to grain in the dry state & 63,39 & S-07 & Compression stress par to grain & in the green state (MPa) & 37,73 & B-37 \\
\hline
\end{tabular}

Figure 1. Index card of Tabebuia rosea (Roble flor morado).

To select a group of species for bowed timber application we divide the selection in two parts according to two groups of criteria. In this order of priority the criteria of first level are:

C1. Mechanical characteristics.

C2. Origin of the wood, selecting native prior to introduced species.

C3. Absence on the red list of the International Union for Conservation of Nature as in (Lopez et al. 2010).

C4. Presence on the reforested species list according to the "Programa Colombia Forestal" as in (Hernández-Córdoba 2006). 
Criterion $\mathrm{C} 1$ is a numerical ordering value. Criterion $\mathrm{C} 2$ is a simple exclusion selection. Criteria $\mathrm{C} 3$ and C4 work logically as follows: C3 V V4 (exclusion is a consequence of a double not).

In regard with mechanical characteristics $(\mathrm{C} 1)$ it is important to explain variables taken in consideration for comparison as follows: in Figure 2 is shown the stress vs. strain diagram of an specimen tested on site. The proportionality limit point $\mathrm{p}\left(\varepsilon_{p}, \sigma_{p}\right)$ is defined as the point where the stress-strain curve leaves the approximately linear behavior as identified by the straight line $\mathrm{E}$. Note that $\mathrm{E}$ is closer fitting with the first part of the stress-strain curve (which is slightly non-linear in general). The peak point $\mathrm{y}\left(\varepsilon_{y}, \sigma_{y}\right)$ is defined as the maximum stress point at the failure of the specimen.

In order to make a ranking of species for bowed wood applications the selection should be done by their largest strain at the proportionality limit point, at the peak point (or another point belonging to stress vs. strain curve) but for the purpose of this paper the selection is done based on the fictitious strain value $\bar{\varepsilon}=\frac{\sigma_{y}}{E}$. In Figure 2 is shown, the value $\bar{\varepsilon}$ used because mechanical characteristics are taken in the majority of cases from the current Colombian construction standard, i.e. the chapter on wood (A.I.S. 2010), which gives only $\sigma y$ and $E$ as material characteristics. Stress values in this publication are at the peak point $\sigma_{y}$ and not at the proportionality limit point $\sigma_{p}$.

For values included in the database coming from (A.I.S 2010), the following conversion is used:

$$
\sigma_{y}=\frac{\sigma_{b, a d m, 0}}{0,166}
$$

Where $\sigma_{b, a d m, 0}$ is the permissible bending stress given in the source (MPa).

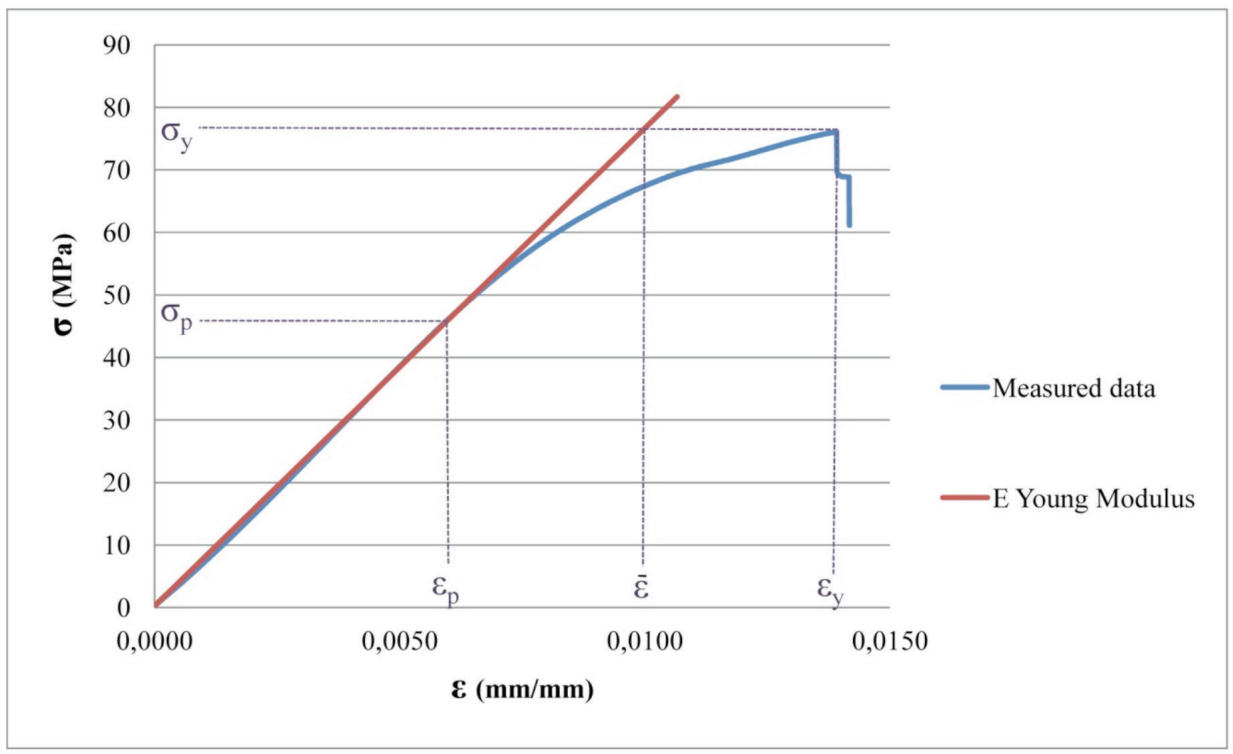

Figure 2. Bending test. Specimen: T-03-08. Stress vs. Strain diagram. 
The minimal radius of curvature that can be given to a beam is related to the size, shape of the beam, and to the strain at the peak point $\varepsilon_{y}$ by the equation:

$$
R_{\min }=\frac{y *}{\varepsilon_{y}}
$$

Where $y^{*}$ is a length related to the size and shape of the beam cross section (e.g. $y^{*}=\frac{\boldsymbol{h}}{2}$ if if the section is a rectangle of height $h$ ).

To simplify matters a more conservative equation is considered here:

$$
\bar{R}_{\min }=\frac{y *}{\bar{\varepsilon}} ; \bar{\varepsilon}=\frac{\sigma_{y}}{E}
$$

The first selection made on the basis of first level criteria is refined by comparing information concerning second level criteria.

Criteria of second level for the selection of species are:

C5. Capacity to dry naturally.

C6. Capacity not to deform during drying.

C7. Natural durability to bio-hazard.

C8. Availability on the market.

Criteria $\mathrm{C} 5, \mathrm{C} 6$, and $\mathrm{C} 7$ is a numerical ordering value. Criterion $\mathrm{C} 8$ is a simple exclusion selection.

The capacity to dry in the original database is divided into three categories: the capacity to dry artificially, the capacity to dry naturally, and the capacity not to deform during drying. We have actually taken into consideration only the last two categories in order to select a species by the least artificial means possible.

\section{Materials and methods for bending stress tests}

In Colombia only a few species sold on the market are certified. Species used for bending tests bought on the market are identified by their macroscopic characteristics.

The species recognition for the purpose of this paper is done using two independent procedures. One procedure is to compare the specimen of the selected species with the information given in (VásquezCorrea and Ramírez-Arango 2005). In case there is no macroscopic information published because some of the species selected are not common, the second procedure is to bring the specimen to the "Laboratorio de Maderas" of the "Universidad Distrital Francisco Jose de Caldas" where they make the species recognition.

Bending tests are done, based on A.S.T.M. standard methodology according to reference (A.S.T.M 1994) with the following procedure:

The size of specimens shall be made on $50 \mathrm{~mm}$ by $50 \mathrm{~mm}$ by $760 \mathrm{~mm}$ primary method specimens or $25 \mathrm{~mm}$ by $25 \mathrm{~mm}$ by $410 \mathrm{~mm}$ secondary method specimens. Tests are done using the secondary method. The actual height and width at the center and the length is measured. We apply the load at the center of supports with a span between supports of $360 \mathrm{~mm}$ at least. These spans are established in order to maintain a minimum span-to-depth ratio of 14 . Tests are done with a fixed support assembly with a span of $375 \mathrm{~mm}$. In relation with the placement of growth rings, we place the specimen so that the load will be applied through the bearing block to the tangential surface nearest the pith. 
In regard to speed of testing, we apply the load continuously throughout the test at a rate of motion of the movable crosshead of $1,3 \mathrm{~mm} / \mathrm{min}$. Load-deflection curves are recorded to or beyond the maximum load for all static bending tests. Within the proportional limit, deflection readings are taken to $0,02 \mathrm{~mm}$. After the proportional limit is reached, less refinement is necessary in observing deflections, but it is convenient to read them by means of the dial indicator until it reaches the limit of its capacity. Deflections are read to the nearest $0,2 \mathrm{~mm}$ at $2,5 \mathrm{~mm}$ intervals and also after abrupt changes in load. We classify the static bending failures in accordance with the appearance of the fractured surface and the manner in which the failure develops. We measure the gravimetric water content of the specimen immediately after using the methodology described on the A.S.T.M. standard (A.S.T.M 1992).

The gravimetric water content is calculated by the equation:

$$
\omega=\frac{m-m_{o}}{m_{o}} \times 100
$$

Where $m$ is the mass of the original specimen, and $m_{o}$ is the mass of the oven-dry specimen.

In the case of saturated specimens, bending tests are done after dipping them in water more than two weeks.

Strain, stress, and Young modulus are calculated by equations as in (A.S.T.M. 2005a):

$$
\begin{gathered}
\varepsilon=\frac{6 \times \mathbf{h} \times \mathbf{f}}{l^{2}} \\
\sigma=\frac{3 \times F \times l}{2 \times b \times h^{2}} \\
\mathbf{E}=\frac{\sigma}{\varepsilon}
\end{gathered}
$$

Where $\mathrm{f}$ is the deflection $(\mathrm{mm}), 1$ is the span $(\mathrm{mm}), \mathrm{b}$ is the specimen's width $(\mathrm{mm}), \mathrm{h}$ is the specimen's height $(\mathrm{mm})$, and $\mathrm{F}$ is the load $(\mathrm{N})$. There are some theories according to (Lastra-Rivera 1987) and (Trouy-Triboulot and Triboulot 2001) on how to correct a mechanical value of a specimen tested at specific gravimetric water content to estimate the value at the $12 \%$ of gravimetric water content. We use the correction standard according to (Lastra-Rivera 1987), but consider also the restricted range of $6 \%$ and $20 \%$ given by (Trouy-Triboulot and Triboulot 2001). In the case of specimens in the dry state, because average gravimetric water content of wood in Bogota is $16 \%$, in order to have values at the $12 \%$ we calculate the mechanical value by the equation:

$$
\begin{aligned}
& \sigma^{1 \mathbf{2}}=\sigma \times(1+k \times(\omega-12)) \\
& E^{1 \mathbf{2}}=E \times(1+k \times(\omega-12))
\end{aligned}
$$

Where, $\omega$ is the gravimetric water content of the specimen, $\sigma$ is the stress, and $E$ is the Young modulus resulting from tests.

Values of correction factors $\mathrm{k}$ are taken from the Table 1 as in (Lastra-Rivera 1987). 
Table 1. Values of correction factors k (Lastra-Rivera 1987).

\begin{tabular}{|c|c|}
\hline Young modulus or stress & Correction factor k \\
\hline$\sigma_{p}$ Stress at the proportionality limit & 5 \\
\hline$\sigma_{y}$ Stress at the peak & 4 \\
\hline E Module Young & 2 \\
\hline
\end{tabular}

\section{RESULTS}

First, we present results of the selection of species more suitable for bowing applications. Then, we present results of tests of selected species.

\section{Selecting a group of species based on mechanical data of timber in the green state}

The strain at the value $\bar{\varepsilon}$ in the green state of 68 tropical (Colombian) species is been compiled from references that have been described in section materials and methods for the selection of species.

The best 55 species shown in figure 3 are selected on the basis of the criterion $\mathrm{C} 2$ presented in the same section, where Teka (Tectona grandis), Cipres (Cupressus lusitanica), and Carbonero (Licania tomentosa) are introduced species that must been disregarded. With regard to the first species, the information is taken from reference (Nieto 2004) and with regard to the other two species from reference (Lopez et al. 2010).

On the basis of the criterion $\mathrm{C} 3$, the following species must be disregarded: Abarco (Cariniana legalis), Aceituno (Humiriastrum colombianum), Alatripe (Cordia alliodora), Balsamo (Myroxilon balsamum), Caoba palo santo (Swietenia macrophylla), Carreto (Aspidosperma dugandii), Cativo (Prioria copaifera), Cedro caqueta (Cedrela odorata), Choiba (Dipterix oleifera), Guayacan polvillo (Tabebuia serratifolia), and Punte or Candado (Minquartia guianensis). These species are on the red list of the I.U.C.N. and are not on the reforested species list. 


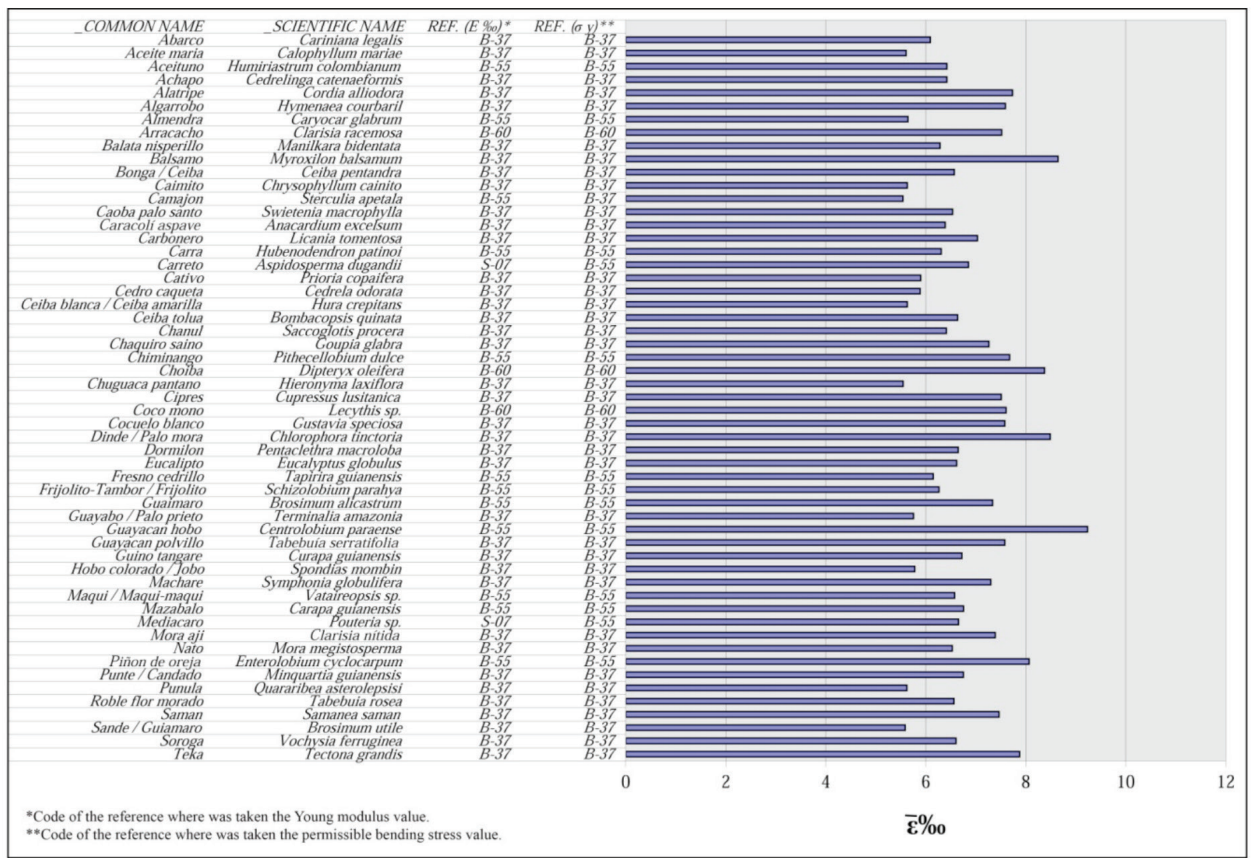

Figure 3. Selection of best 55 tropical (Colombian) species ranked according to the strain at the value $\bar{\varepsilon}$ in the green state.

Of the remaining 41 species, a ranking is been done according to criterion $\mathrm{C} 5$ (their capacity to dry naturally), criterion C6 (their capacity not to deform during drying), and criterion $\mathrm{C} 7$ (their natural durability to bio-hazard). A raking according to criterion C5 is shown in figure 4. Values shown in blue correspond to a grade we give to qualitative information taken from reference (Escobar and Rodriguez 1993) corresponding to code B-37. Values shown in red are taken from reference (J.U.N.A.C 1984) corresponding to code B-44. The deviation from one reference to the other is very small, the level of accuracy can be considered as acceptable. 


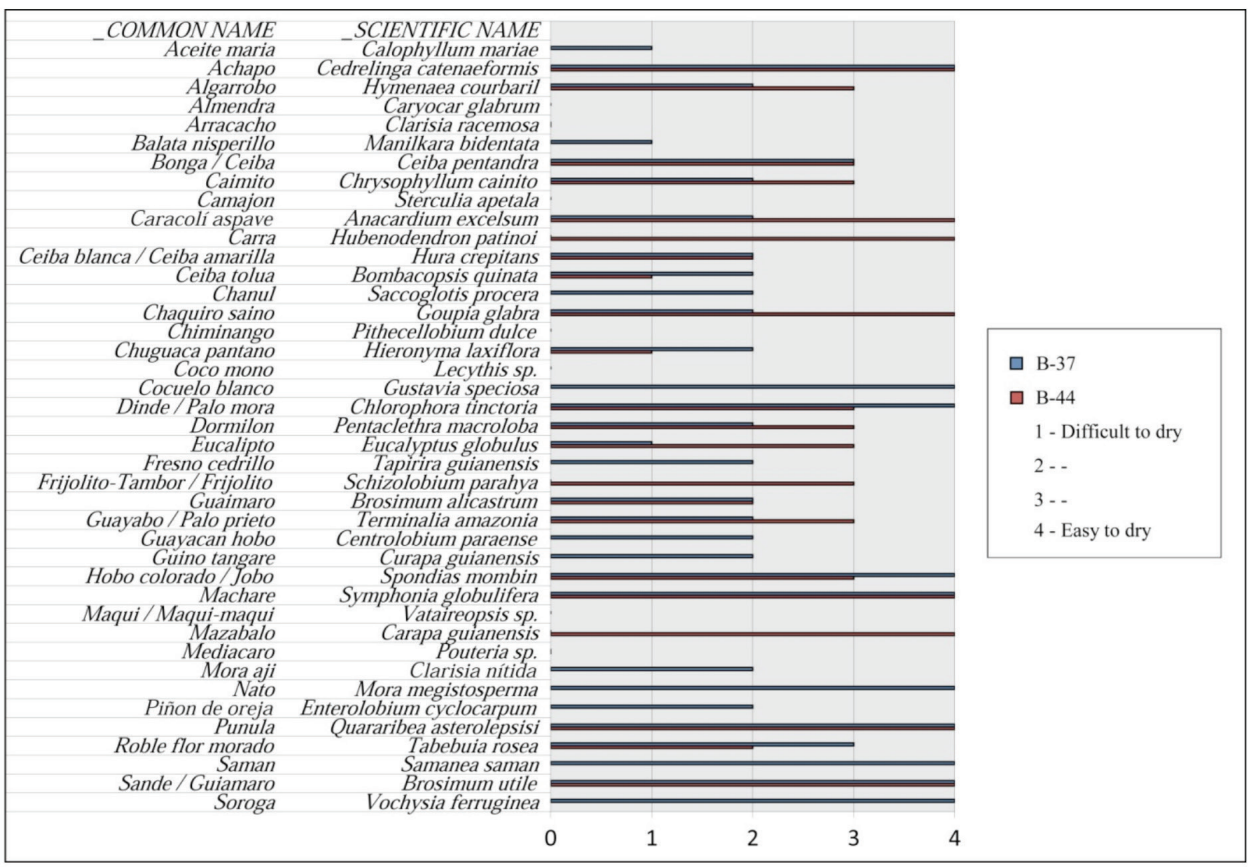

Figure 4. Ranking comparing capacity to dry naturally per species.

A ranking according to criterion $\mathrm{C} 6$ is shown in figure 5, where drying deformation is based on qualitative information per species. In regard with values shown in figure 6 , a ranking comparing natural durability to bio-hazard per species is taken from reference (Gerard 2008) corresponding to code D-01, and reference (Escobar and Rodriguez 1993) corresponding to code B-37. 


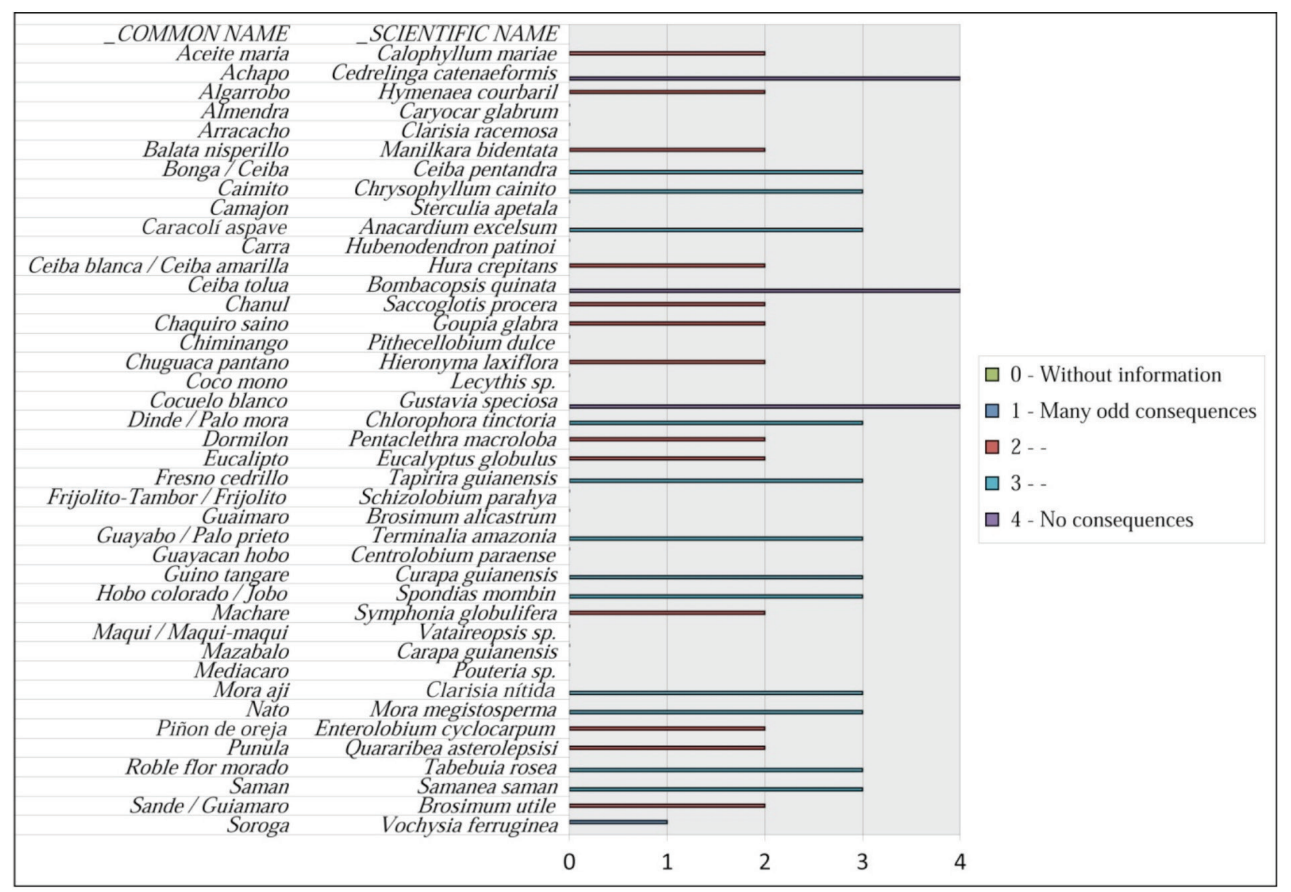

Figure 5. Ranking comparing drying deformations based on qualitative information per species.

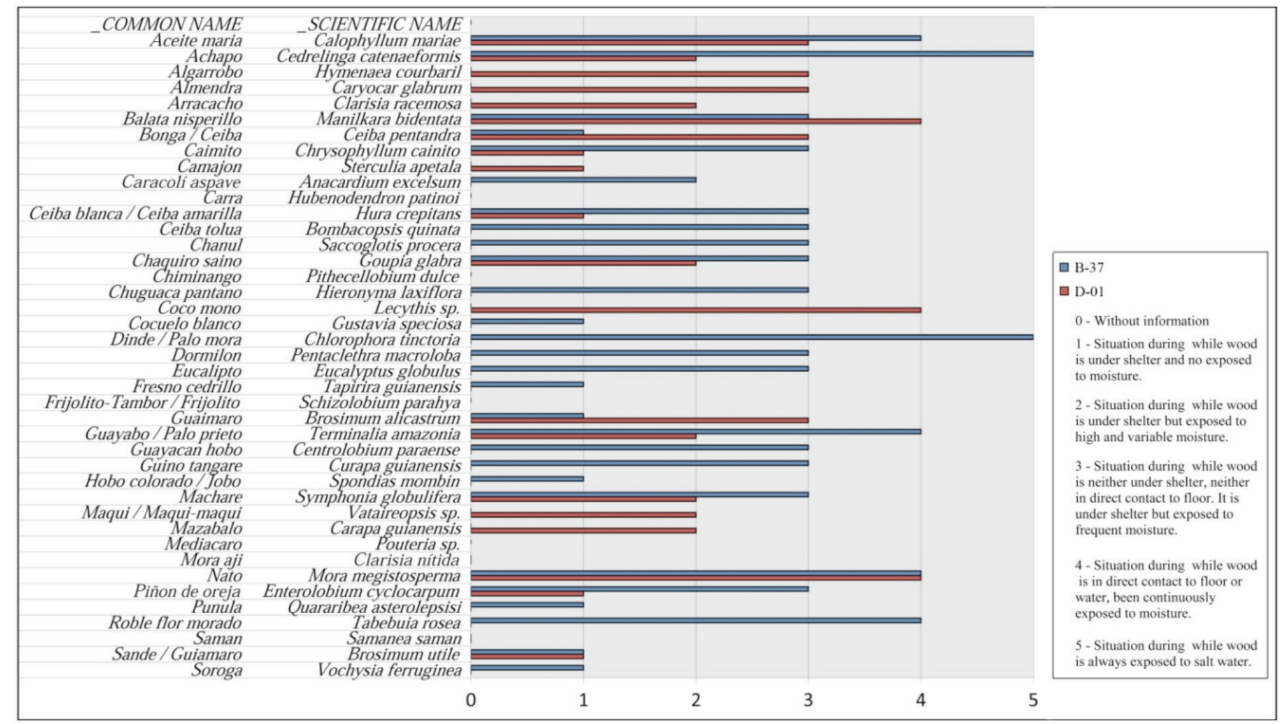

Figure 6. Ranking comparing natural durability to bio-hazard per species. 
Concluding the choice is restricted to 19 species, i.e. in order of priority:

1. Achapo (Cedrelinga catenaeformis)

2. Dinde / Palo mora (Chlorophora tinctoria)

3. Cocuelo blanco (Gustavia speciosa)

4. Caracoli (Anacardium excelsum)

5. Carra (Hubenodendron patinoi)

6. Chaquiro saino (Goupia glabra)

7. Hobo colorado / Jobo (Spondias mombin)

8. Machare (Symphonia globulifera)

9. Mazabalo (Carapa guianensis)

10. Nato (Mora megistosperma)

11. Punula (Quararibea asterolepsisi)

12. Saman (Samanea saman)

13. Sande / Guaimaro (Brosimum utile)

14. Soroga (Vochysia ferruginea)

15. Ceiba tolua (Bombacopsis quinata)

16. Guayabo / Palo prieto (Terminalia amazonia)

17. Roble flor morado (Tabebuia rosea)

18. Bonga / Ceiba (Ceiba pentandra)

19. Caimito (Chryssophyllum cainito)

Therefore, only Tabebuia rosea, Brosimum utile, Ceiba pentandra, Terminalia amazonia, and Bombacopsis quinata are available on the market. We select Tabebuia rosea, Brosimum utile, and Ceiba pentandra in order to complete the investigation with information taken on the site of bending tests.

\section{Selecting a group of species based on mechanical data of timber in the dry state}

The strain at the value $\bar{\varepsilon}$ in the dry state of 131 tropical (Colombian) species is compiled from this references; (A.I.S 2010) corresponding to S-07, (Escobar and Rodriguez 1993) corresponding to code B-37, (Salazar 2010) corresponding to code U-03A, and (Vásquez-Correa and Ramírez-Arango 2005) corresponding to B-55.

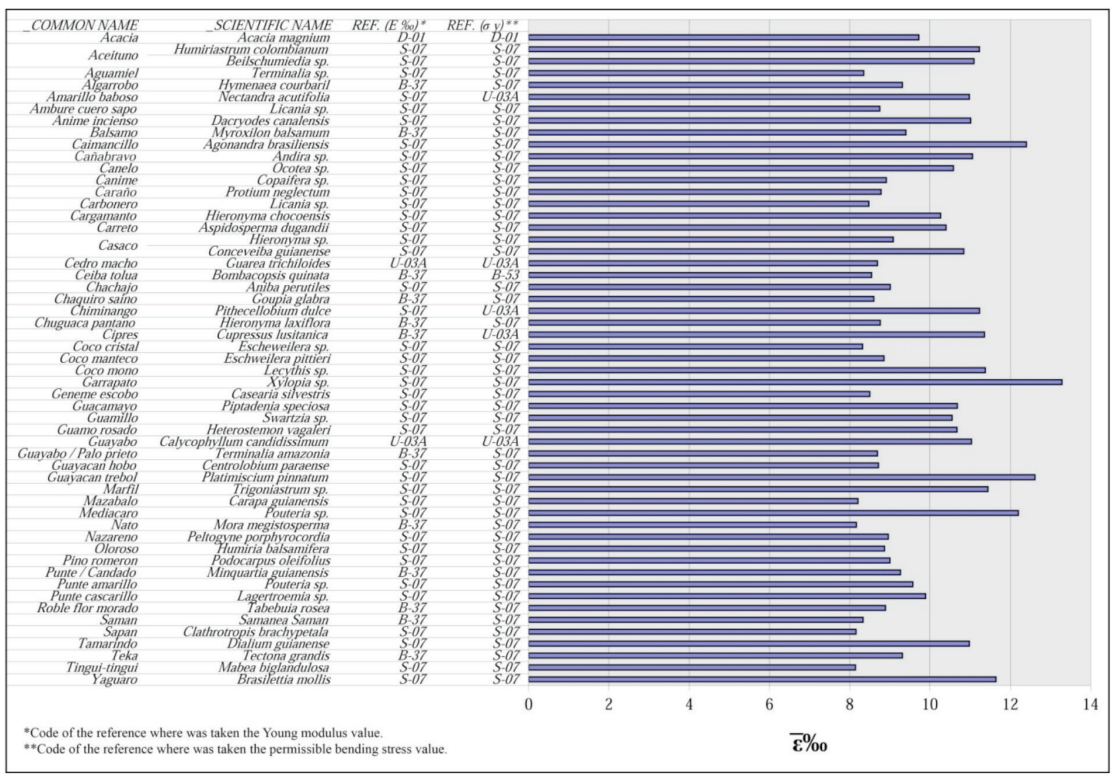

Figure 7. Selection of best 55 (Colombian) species ranked according to the strain at the value in the dry state. 
The best 55 species shown in the figure 7 are selected on the basis of the criterion $\mathrm{C} 2$ established in section materials and methods for the selection of species, where Acacia (Acacia magnium), Cipres (Cupressus lusitanica), and Teka (Tectona grandis) are introduced species that must be disregarded. On the basis of the criterion $\mathrm{C} 3$, the following species must be disregarded: Aceituno (Humiriastrum colombianum), Balsamo (Myroxilon balsamum), Carreto (Aspidosperma dugandii), Cachajo (Aniba perutiles), Nazareno (Peltogyne porphyrocordia), and Punte / Candado (Minquartia guianensis).

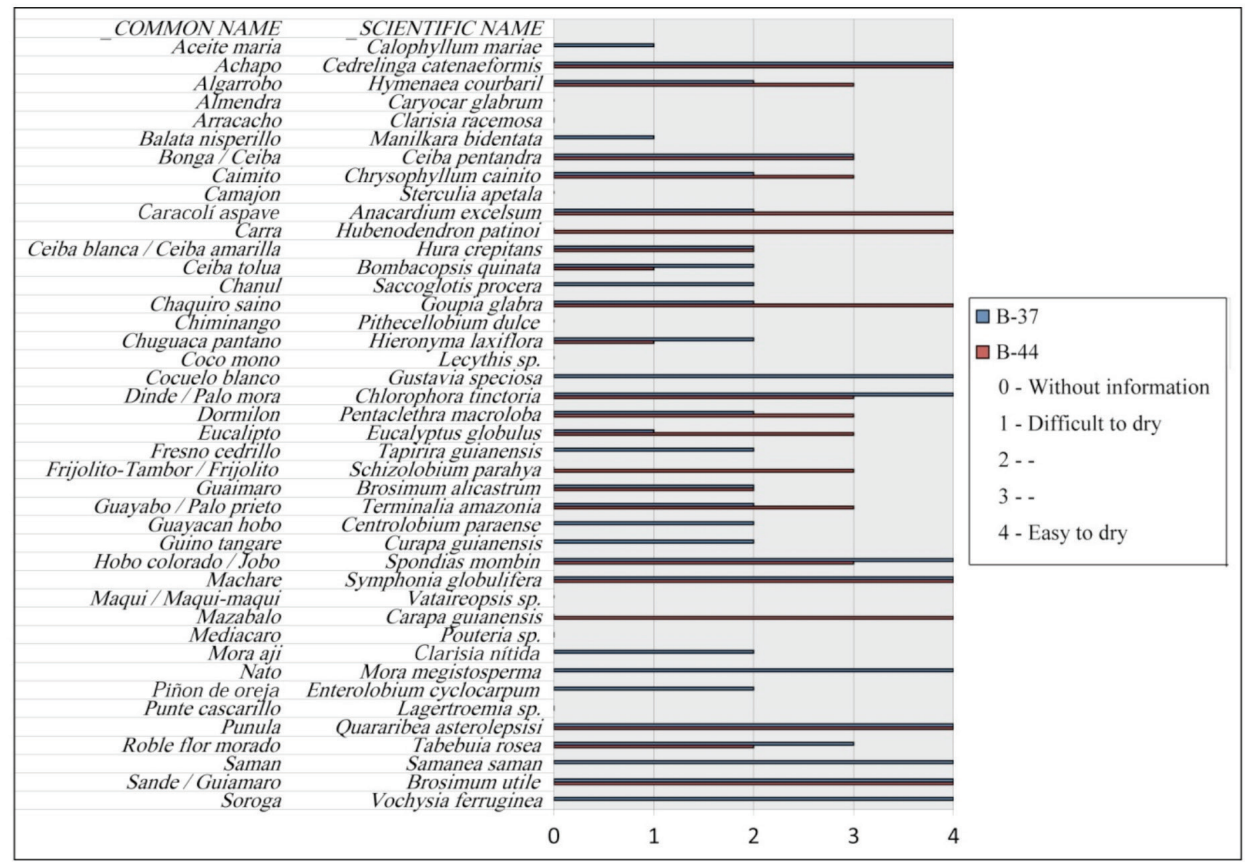

Figure 8. Ranking comparing capacity to dry naturally per species.

Of the remaining 46 species, a ranking is done also according to their capacity to dry naturally shown in figure 8 , their capacity not to deform during drying shown in figure 9 , and natural durability to bio-hazard shown in figure 10 .

Values in figures 8,9 , and figure 10 are taken from the same references than in figure 5 , figure 6 , and figure 7 respectively. Also the same color code for each reference is applied. 


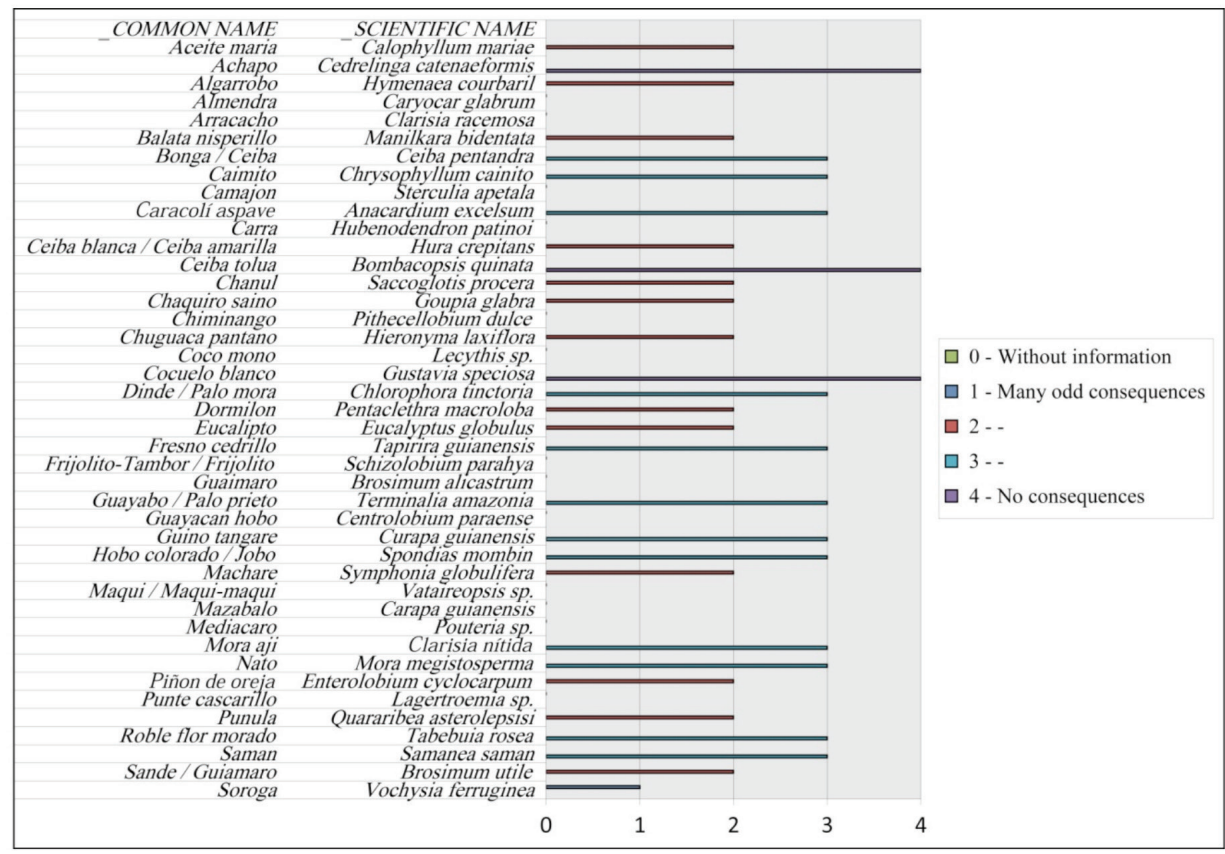

Figure 9. Ranking comparing deformations during drying on the basis of qualitative information.

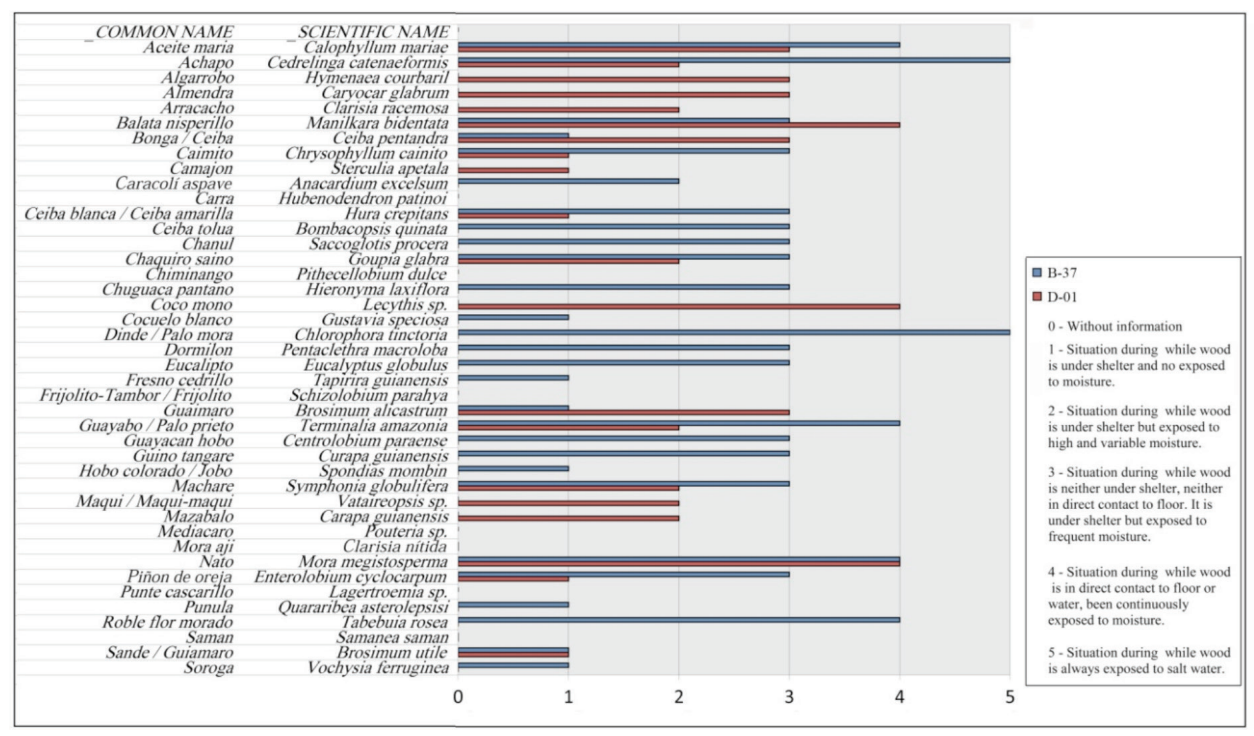

Figure 10. Ranking comparing natural durability to bio-hazard per species. 
According to this information, the choice is restricted to 15 species, i.e. in order of priority:

1. Nato (Mora megistosperma)

2. Casaco (Hyeronima sp.)

3. Pino romeron (Podocarpus oleifolius)

4. Saman (Samanea saman)

5. Achapo (Cedrelinga catenaeformis)

6. Ceiba tolua (Bombacopsis quinata)

7. Cocuelo blanco (Gustavia speciosa)

8. Cañabravo (Andira sp.)

9. Cargamanto (Hieronyma chocoensis)

10. Cedro macho (Guarea trichiloides)

11. Coco mono (Lecythis sp.)

12. Guamillo (Swartzia sp.)

13. Guayabo / Palo prieto (Terminalia amazonia)

14. Roble flor morado (Tabebuia rosea)

15. Tamarindo (Dialum guianense)

Therefore, only Podocarpus oleifolius, Guarea trichiloides, Tabebuia rosea, and Dialum guianense are available on the market. We select Tabebuia rosea, and Dialum guianense in order to complete the investigation with information taken on the site of bending tests.

\section{Geographic description of four selected species}

Based on a geographic criterion, the location of each species per region is shown in Figure 11; the geographic division is taken as in (I.G.A.C 2011). The location based on a political criterion will be described in the followings paragraphs.

Roble flor morado (Tabebuia rosea) characteristics are described in figure 1. With a $540 \mathrm{~kg} / \mathrm{m}^{3}$ density (A.I.S 2010) it belongs to group C according to the "Junta del Acuerdo de Cartagena" ranking (J.U.N.A.C 1984), meaning that it is a low density species. According to (Nieto et al. 1998) the yield is $20 \mathrm{~m}^{3} / \mathrm{ha} /$ year, therefore now a day is quite difficult to find these species on the market but in some years it would be easier because it has been chosen for reforestation. 


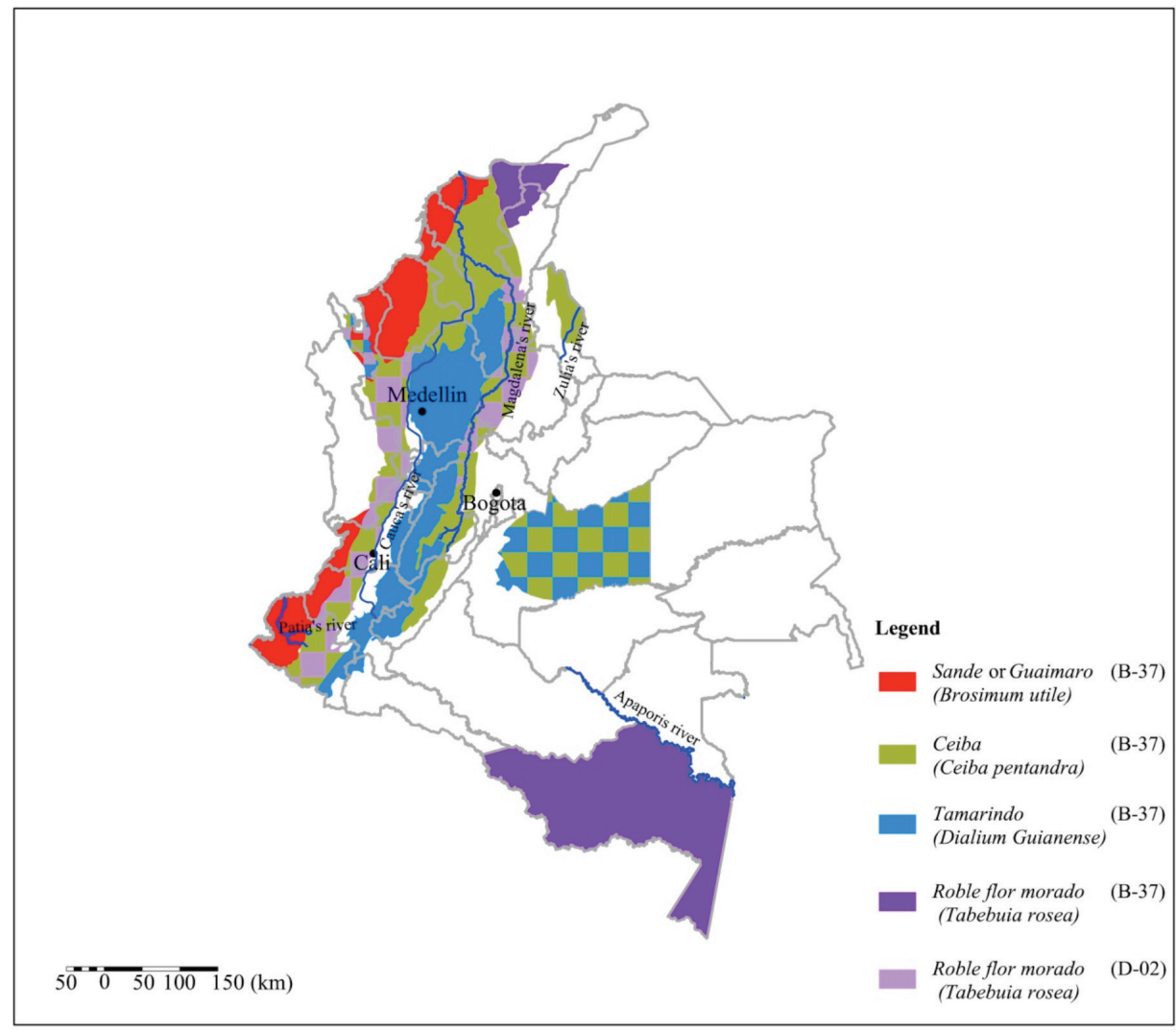

Figure 11. Location per region, the geographic division is taken as in (I.G.A.C 2011).

Bonga or Ceiba (Ceiba pentandra) is also known as Fromager according to (Lopez et al. 2010). With a $210 \mathrm{~kg} / \mathrm{m}^{3}$ density (Vásquez-Correa and Ramírez-Arango 2005), it belongs also to group C. The tree has a medium high of $20 \mathrm{~m}$, a medium diameter of $2 \mathrm{~m}$, and the tree trunk is straight and irregular (Escobar and Rodriguez 1993). The sapwood is white and the heartwood is hard to identify because it gradually turns to light yellow. According to (Lopez et al. 2010), it is located at the canyon of Magdalena's river, Cauca's river, and Zulia's river and the regions of: Urabá, and Llanos Orientales. The annual increment is $1 \mathrm{~cm} /$ year (Obregón-Sánchez 2005).

Sande or Guaimaro (Brosimum utile) has a density of $420 \mathrm{~kg} / \mathrm{m}^{3}$ as in (Lastra-Rivera 1987), it also belongs to group $\mathrm{C}$. The tree has a medium high of $35 \mathrm{~m}$, a medium diameter of $1,5 \mathrm{~m}$, and the tree trunk is cylindrical and straight (Escobar and Rodriguez 1993). The sapwood is light pink and the heartwood is light brown. Latex can be extracted from the tree for rubber production applications, as in (Lopez et al. 2010). According to (Escobar and Rodriguez 1993), it is located at the departments of: Choco, Magdalena, Amazonas, and Putumayo, and regions of: Urabá, Tumaco, Puerto Libano and Bajo Calima. According to (Lopez et al. 2010) it is also located at the departments of: Caqueta, Guaviare, Guainia, Putumayo, and Vaupes.

Tamarindo (Dialum guianense) is also known as Oxwood Maracaibo, Venezuelan Boxwood, West Aian or Aian Boxwood according to (Proexport 1980). With a $880 \mathrm{~kg} / \mathrm{m}^{3}$ density (A.I.S 2010), it belongs to group A, meaning that it is considered as a high density species. The tree has a medium high of 35 $\mathrm{m}$, a medium diameter of $0,8 \mathrm{~m}$, and the tree trunk is straight with small irregularities (Escobar and Rodriguez 1993). The sapwood is light yellow and the heartwood is easy to identify because it is from red brown to dark brown. According to (Escobar and Rodriguez 1993), it is located at the departments 
of: Bolivar, Vaupes, and Antioquia. More precisely, at the regions of: Carare-opon, Puerto Wilches, Cimitarra, Barrancabermeja, Palotal, Ayapel, Urabá, Caucasia, San Luis and San Francisco. It is also located at the peaks of: Macarena, and San Lucas. Furthermore it is located at canyons of rivers Acacias, and Apaporis.

\section{Measured characteristics of the selected species}

The number of specimen to test is 9 or more per species in the dry state and 12 or more per species in the saturated state. The number of trees per test depends on the availability of species on the market. Specimens of Sande or Guaimaro (Brosimum utile) are taken from 2 different trees, specimens of Ceiba (Ceiba pentandra) are taken from 8 different trees, specimens of Tamarindo (Dialum guianense) are taken from the same tree, and specimens of Roble flor morado (Tabebuia rosea) are taken from 7 different trees.

In Figure 12 are shown the test assembly and some of the specimens of the species to test.

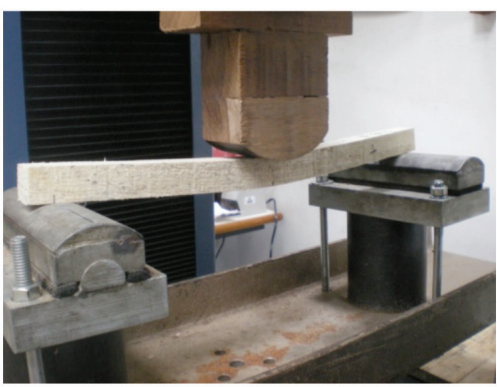

a

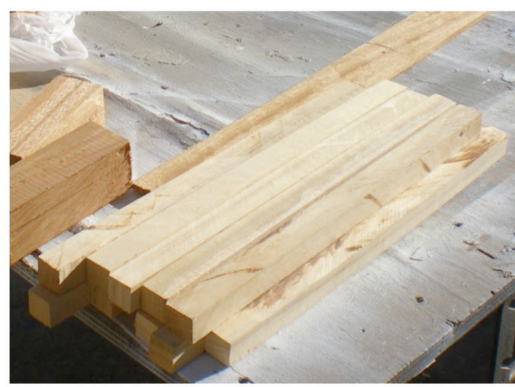

$\mathrm{b}$

Figure 12. a. Static bending test assembly showing load application and specimen support. b. Brosimum utile specimens.

In Table 2 are shown mechanical characteristics that we present (giving U-04 as reference code) based on bending test results taken on site.

Table 2. Mechanical characteristics based on bending test results.

\begin{tabular}{|c|c|c|c|c|c|c|c|}
\hline Scientific name & $\begin{array}{c}\text { Common } \\
\text { name }\end{array}$ & $\begin{array}{c}E \% \text { Young } \\
\text { modulus. } \\
\text { Dry state } \\
(\mathrm{MPa})\end{array}$ & $\begin{array}{c}\sigma_{y} \\
\text { Bending } \\
\text { stress. } \\
\text { Dry state } \\
(\mathrm{MPa})\end{array}$ & $\begin{array}{c}\bar{\varepsilon} \% \\
\text { Strain. } \\
\text { Dry state }\end{array}$ & $\begin{array}{c}E \% \mathrm{Y} \\
\text { Young } \\
\text { modulus. } \\
\text { Saturated } \\
\text { state } \\
(\mathrm{MPa})\end{array}$ & $\begin{array}{c}\sigma_{y} \\
\text { Bending } \\
\text { stress. } \\
\text { Saturated } \\
\text { state } \\
(\mathrm{MPa})\end{array}$ & $\begin{array}{c}\overline{\bar{\varepsilon}} \% \\
\text { Strain. } \\
\text { Saturated } \\
\text { state }\end{array}$ \\
\hline Brosimum utile & $\begin{array}{c}\text { Sande } \text { or } \\
\text { Guaimaro }\end{array}$ & 9,29 & 90,55 & 0,102 & 10,38 & 79,2 & 0,131 \\
\hline $\begin{array}{c}\text { Ceiba } \\
\text { pentandra }\end{array}$ & $\begin{array}{c}\text { Bonga } \text { or } \\
\text { Ceiba }\end{array}$ & 5,65 & 52,24 & 0,108 & 6,32 & 45,2 & 0,139 \\
\hline $\begin{array}{c}\text { Dialum } \\
\text { guianense }\end{array}$ & Tamarindo & 14,25 & 132,86 & 0,107 & 16,93 & 114,73 & 0,147 \\
\hline Tabebuia rosea & $\begin{array}{c}\text { Roble flor } \\
\text { morado }\end{array}$ & 7,80 & 83,64 & 0,093 & 8,73 & 83,47 & 0,104 \\
\hline
\end{tabular}




\section{DISCUSSION}

\section{What the result mean}

It is important to do the comparison in terms of the fictitious strain value $\bar{\varepsilon}$ described in section materials and methods for the selection of species. Lower values correspond to species with a water gravimetric content more suitable for bowing applications.

First we conclude, between strains $\bar{\varepsilon}$ in the dry state to the strains $\bar{\varepsilon}$ in the saturated state, the first one is always smaller. Consequently, these species are more suitable for bowing in the dry state than in the saturated state. Results shown do not confirm the hypothesis. It can be explained because green wood is different from wet or saturated wood. Even if the gravimetric water content in both cases is equivalent, green wood differs because it is freshly sawn wood and saturated wood can be old. According to (Ishimaru et al. 2001), it is known that wood conditioned from a dry state has higher elasticity and strength than wood conditioned from a water-saturated state with equal gravimetric water content. It means that some mechanical properties vary not only because of modifications of the gravimetric water content but also because of modifications of the cellulose chain during the adsorption and the desorption process.

Furthermore according to (McMillen et al. 1958), wood is mainly subjected to a tension stress during drying. Hence, comparing wood in the green state to wood in the saturated state, the first one is usually more resistant because tension stress is partly counter balancing the compression stress due to bending.

Second we conclude, with those wood species, a shaft $30 \mathrm{~cm}$ thick can be bow in the dry state to reach a curvature radius of 14 to $16,2 \mathrm{~m}$ applying the equation (2) presented in section materials and methods for the selection of species, demonstrating the viability of the idea of using this species to build arches. Nevertheless, we recommend to do experiments with wood in the green state making sure wood is not in a saturated state to verify if these species are more suitable for bowing in the green state than in the dry state.

In order to verify the deviation of information taken from different references it is more representative to take information on timber in the dry state because there is little information on timber in the green state.

References in Figure 13 and in Figure 14 are described on the section materials and methods for the selection of species, except U-03A and U-03B, that refers to Salazar 2010. On the same reference two values are published for the same species. 


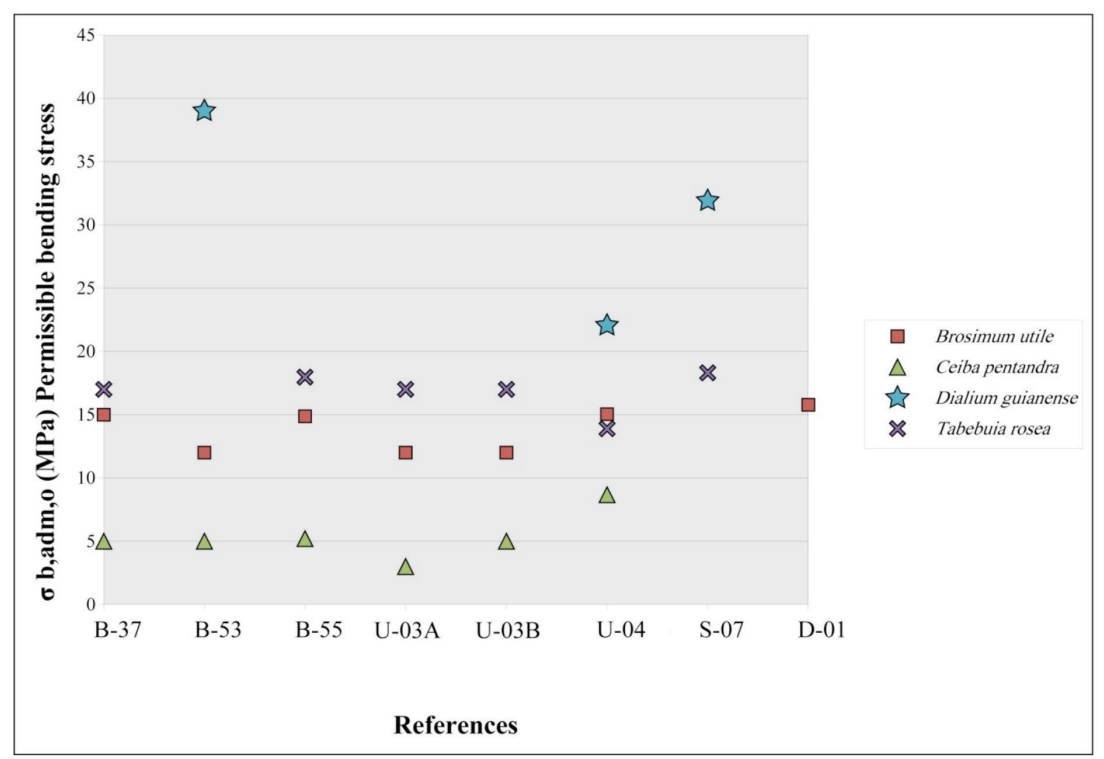

Figure 13. Permissible stress based on bending tests in the dry state.

Bending stress results of most species shown in Figure 13 are in good agreement with each other.

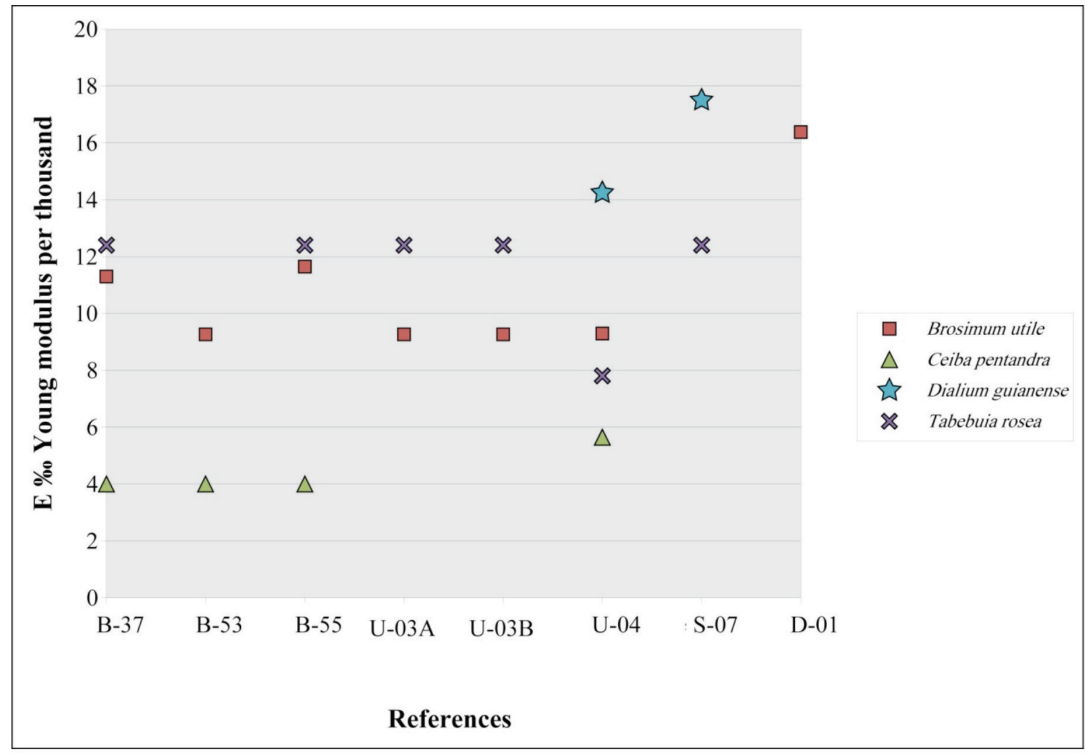

Figure 14. Young modulus per thousand based on bending tests in the dry state.

Young modulus's results with regard to Sande or Guaimaro (Brosimum utile), Ceiba or Bonga (Ceiba pentandra), and Tamarindo (Dialum guianense) shown in Figure 14 are in good agreement with each other, while values regarding Roble flor morado (Tabebuia rosea) differ considerably between each other. To conclude we reconfirm that the species most suitable for bowing applications is Roble flor morado (Tabebuia rosea).

\section{How the results can be applied}

Results concerning the selection of species are useful in terms of the recommendation of species that should be considered for reforestation in Colombia. 
Results concerning measured characteristics of the selected species may encourage laboratories in developing countries to make mechanical tests of some rare species with very few information published.

\section{CONCLUSIONS}

In the section selecting a group of species based on mechanical data of timber in the green state 19 species most suitable for bowing are selected. In section selecting a group of species based on mechanical data of timber in the dry state 15 species most suitable for bowing are selected. Merging these lists there are 34 species in total from which 4 species are selected in order to complete the investigation with information taken on site.

To conclude, with those wood species, a shaft $30 \mathrm{~cm}$ thick can be bow in the dry state to reach a curvature radius of 14 to $16,2 \mathrm{~m}$, showing the viability of the idea of using this species for bowing applications. We also recommend the other 30 species for bowed timber applications but verification tests are required due to important differences of mechanical information published.

We consider more work should be done in particular regarding the compilation of information into the existing database. The more information the database has the more precise results are.

This paper can help users of wood when a methodology to select of a group of species is required, even for a different application. As well it can be useful to many laboratories in developing countries where research and testing facilities are limited.

\section{ACKOWLEDGEMENT}

This paper would not have been possible without the guidance of my supervisor, Maurizio Brocato. I am also grateful to Professor Olavo Escorcia and the research group "Madera y Guadua" of the "Universidad Nacional de Colombia", for the support and for giving me the chance to work at their laboratory.

\section{REFERENCES}

Asociacion Colombiana de Ingenieria Sismica. A.I.S. 2010. Nuevo Reglamento Colombiano de Construcción Sismoresistente NSR-10. Titulo A - Requisitos generales de diseño y construcción sismo-resistente. Decreto N 926 del 19 de Marzo del 2010.

American Society for Testing and Materials. A.S.T.M. 1992. Standards in building codes : specifications, test methods, practices, classifications, definitions. Standard test methods for direct moisture content measurement of wood and wood-base materials. A.S.T.M. 1992 D4442. West Conshohocken. PA.

American Society for Testing and Materials. A.S.T.M. 1994. D143. Standards in building codes : specifications, test methods, practices, classifications, definitions. Standard test methods for small clear specimens of timber. A.S.T.M. 1994 D143. West Conshohocken. PA.

American Society for Testing and Materials. A.S.T.M. 2005a. D4761. Standard test methods for mechanical properties of lumber and wood-base structural material. A.S.T.M. 2005a D4761. West Conshohocken. PA.

Gerard, J. 2008. Tropix 06 : Caractéristiques technologiques de 245 essences tropicales. [Online] <http://tropix. cirad.fr/ame.html> [accessed : 21-01-2011].

Hernández-Córdoba, D. 2006. Modelos de desarrollo sostenible en Colombia: de la utopía a la realidad. Revista $M \& M$ 52: 33-36. 
I.G.A.C. 2011. Mapas temáticos predefinidos. Nacional. Ambiental. Zonas hidrogeológicas. [Online] <http://sigotn. igac.gov.co/sigotn $>$ [accessed : 21-11-2011].

Ishimaru, Y.; Arai, K.; Masato, M.; Oshima, K.; Iida, I. 2001. Physical and mechanical properties of wood after moisture conditioning. Journal of Wood Science 47 : 185-191.

Junta del Acuerdo de Cartagena. J.U.N.A.C. 1984. Manual de diseño para maderas del Grupo Andino. 3 edn. Proyectos andinos de desarrollo tecnólogico en el área de los recursos forestales tropicales. Lima, Peru, P.A.D.T.R.E.F.O.R.T.

Lastra-Rivera, J. A. 1987. Compilación de las propiedades fisico mecánicas y usos posibles de 178 maderas de Colombia. Bogotá, Colombia, A.C.I.F., 74p.

Lopez, C. R.; Navarro, L.J. A.; Montero, G.p M. I.; Amaya, V.p K.; Rodríguez, C. 2010. Catálogo de biodiversidad en Colombia. [Online] <http://www.siac.net.co/sib/catalogoespecies/welcome.do> [Accessed : 21-01-2011].

McMillen, J. M. 1958. Stresses in wood during drying. Report. Forest Products Laboratory U.S. Dept. of Agriculture, Forest Service, Forest Products Laboratory. no. 1652. Madison.

Nieto, V. 2004. Las Diez Especies Top para Investigación y Desarrollo Forestal. Revista M\&M 46: 7pp.

Nieto, V.; Cardenas, R.; Herrera-Chitiva, G. 1998. Plan estratégico para el mejoramiento genético de Cordia alliodora y Tabebuia rosea en Colombia. Santafe de Bogotá, Colombia, Ministerio de Agricultura y Desarrollo Rural Corporación Nacional de Investigación y Fomento Forestal, 40p.

Obregón-Sánchez, C. 2005. Bajo la Sombra de la Ceiba... el Árbol de la Vida. Revista M\&M 48: 13-20.

Proexport. 1980. Maderas colombianas. Bogotá, Colombia, Italgraf, 117p.

Proexport. 2009. Sector forestal en Colombia. Cartilla Forestal. Bogotá, Colombia, Fiducoldex - Fideicomiso Proexport Colombia, 26p.

Rojas-Gutiérrez A.M. 2008. Nogal cafetero: más que una especie ideal para Agroforestería. Revista M\&M 61 : 9-16.

Salazar, J. 2010. Propiedades mecánicas maderas colombianas. Bogotá, Colombia, In press.

Escobar, O.; Rodriguez, J.R. 1993. Las maderas en Colombia. Medellin, Colombia, S.E.N.A, 75p.

Sautu, A. ; Baskin, J.M. ; Baskin, C.C. ; Condit, R. 2006. Studies on the seed biology of 100 native species of trees in a seasonal moist tropical forest, Panama, Central America. Forest Ecology and Management 234 (1-3): 245-263.

Triana-Gómez, M.A.; Gonzalez-Roso, G.; Paspur-Posso, S.D. 2008. Estudio de las propiedades mecánicas de la madera de Palosangre (Brosimum rubescens taub.), procedencia Leticia, Amazonas. Colombia Forestal 11:149-164.

Teranishi, M.; Koizumi, A.; Hirai T. 2008. Evaluation of quality indexes of bending performance and hardness for hardwoods. Journal of Wood Science 54(5): 423-428.

Trouy-Triboulot, M.C.; Triboulot, P. 2001. Matériau bois: Structure et caractéristiques. Paris, France, Techniques de l'ingénieur : 1-26.

Universidad Distrital Francisco José de Caldas. U.D.F.J.C. 2010. Herbario Virtual. [Online] <http:/herbario. udistrital.edu.co/herbario/.> [Accessed : 21-01-2011].

Vásquez-Correa, A.M.; Ramírez-Arango, A.M. 2005. Maderas comerciales en el Valle de Aburrá. Medellin, Colombia, Área Metropolitana del Valle de Aburrá. 246p.

Vázquez-Yanes, C.; Batis-Muñoz, A.I.; Alcocer-Silva, M.I.; Gual-Díaz, M.; Sánchez-Dirzo, C. 1999. Arboles y arbustos nativos potencialmente valiosos para la restauración ecológica y la reforestación. Reporte técnico del proyecto J084. CONABIO. Mexico D.F., Mexico, Instituto de Ecología, UNAM. 13p. 